\title{
Diagnosis Of Hospital, Hazardous and Similar Waste Management of an Institution Providing Health Services - IPHS
}

\author{
Diagnóstico de la gestión de residuos hospitalarios, peligrosos y similares de \\ una institución que proporciona servicios de salud - IPHS \\ Diagnóstico da manejo hospitalar, perigoso e semelhante de uma instituição \\ prestadora de serviços de saúde - IPHS
}

\author{
David Eduardo Aparicio Plazas ${ }^{1}$ \\ Diego Hernando Angulo Flórez ${ }^{2}$ \\ Edna Carolina Cipagauta Esquivel ${ }^{3}$ \\ Diego Alejandro Barragán Currea ${ }^{4}$ \\ Rosmy Johana Zipa Romero ${ }^{5}$
}

Received: May $10^{\text {th }}, 2020$

Accepted: July $14^{\text {th }}, 2020$

Available: September $2^{\text {th }}, 2020$

How to cite this article:

D. E. Aparicio Plazas, D. H. Angulo Flórez, E. C. Cipagauta Esquivel, D. A. Barragán Currea, R. J. Zipa Romero, "Diagnosis of Hospital, Hazardous And Similar Waste Management Of An Institution Providing Health Services - IPHS," Revista Ingeniería Solidaria, vol. 16, no. 3, 2020. doi: https://doi.org/10.16925/2357-6014.2020.03.09

Artículo de investigación. https://doi.org/10.16925/2357-6014.2020.03.09

Universidad Nacional Autónoma de México - UNAM.

Email: deaparicio@uniboyaca.edu.co,david.aparicio@atmosfera.unam.mx

ORCID: https://orcid.org/0000-0002-4111-0551

CvLAC: http://scienti.colciencias.gov.co:8081/cvlac/visualizador/generarCurriculoCv.do?cod_rh=0001464987

2 Fundación Universitaria Juan de Castellanos-FUJDC

Email: dangulo@jdc.edu.co/ diego.angulo@uptc.edu.co

ORCID: https://orcid.org/0000-0002-8693-1097

ID SCOPUS: 57193257128

CVLAC: https://scienti.minciencias.gov.co/cvlac/visualizador/generarCurriculoCv.do?cod_rh=0000007995

3 Docente de tiempo completo, Facultad de Ciencias e Ingeniería, Universidad de Boyacá - UdB. Magíster en Química,

Programa en pos-graduación Red Minera de Química. Universidad Federal de São João del-Rei - UFSJ.

Email: eccipagauta@uniboyaca.edu.co

ORCID: https://orcid.org/0000-0001-9982-9350

ID SCOPUS: 57212219091

CvLAC: https://scienti.minciencias.gov.co/cvlac/visualizador/generarCurriculoCv.do?cod_rh=0001577432

$4 \quad$ Secretaria de educación de Bogotá

Email: dabarraganc@educaciónbogota.edu.co

ORCID: https://orcid.org/0000-0003-4491-9273

CVLAC: https://scienti.minciencias.gov.co/cvlac/visualizador/generarCurriculoCv.do?cod_rh=0000437581

$5 \quad$ Universidad Pedagógica y Tecnológica de Colombia - UPTC

Email: zipajohana@gmail.com / rouss-78@hotmail.com

ORCID: https://orcid.org/0000-0003-1488-1374

CVLAC: https://scienti.minciencias.gov.co/cvlac/visualizador/generarCurriculoCv.do?cod_rh=0001553812 


\section{Abstract}

Introduction: This article presents the results of the research carried out from January 2018 to December 2019, in an institution providing third-level health services (IPHS), located in Tunja (Boyacá), in eastern central Colombia.

Problem: There are various difficulties related to the management of waste produced by the IPHS; Irresponsible practices cause the spread of infections, which have repercussions in critical situations locally, regionally and internationally.

Objective: To evaluate the management of hospital, hazardous and similar waste (HCWM), carried out by an IPHS, and to formulate strategies for its improvement.

Methodology: The research was carried out in three (3) stages: data collection (through inspections and weighing of waste), data analysis (for the qualification and quantification of the waste), and finally, some guidelines for its proper management were proposed, based on the context of the organization.

Results: The IPHS generated 397.6 tonnes of hospital, hazardous and similar waste (MW). Biohazard waste (BW) predominated over the others $(54.11 \%)$, followed by usable non-hazardous waste - UNHW (41.53\%) and chemical and pharmaceutical waste - CPW (4,37\%).

Conclusion: The entity complies with the main requirements of the national government, identifying good utilization and biosecurity practices; however, under diagnosis and with the implementation of guidelines emanating from research, it is possible to optimize procedures.

Originality: The guidelines and activities for the separation, use and internal collection of waste within an IPHS were observed and then interrelated with the services provided and their resources. This work could be a guideline for related institutions.

Limitations: The article focuses on the internal and non-external management of MW.

Key Words: Hospital waste - MW, hazardous waste management, biosecurity, hospital or health service provider institution - IPHS, drug and biosanitary waste - HCW, urban solid waste - USW.

\section{Resumen}

Introducción: El artículo expone los resultados producto de la investigación realizada de enero de 2018 a diciembre de 2019, en una institución prestadora de servicios de salud de tercer nivel (IPHS), ubicada en Tunja (Boyacá), al centro oriente de Colombia.

Problema: Existen diversas dificultades relacionadas con el manejo de los residuos producidos por las IPHS; prácticas irresponsables ocasionan la propagación de infecciones que repercuten en situaciones críticas local, regional o internacionalmente.

Objetivo: Evaluar la gestión de residuos hospitalarios y similares (HCWM), realizada por una IPHS, y formular estrategias para su mejoramiento.

Metodología: La investigación se desarrolló en tres (3) etapas: Recopilación de información (a través de inspecciones y pesaje de residuos); análisis de datos (a partir de la cualificación y cuantificación de los residuos); finalmente, fueron propuestas algunas pautas para su adecuado manejo, basadas en el contexto de la organización.

Resultados: La IPHS generó 397,6 toneladas de residuos hospitalarios y similares (MW). En tanto que los residuos de riesgo biológico (BW), predominaron respecto de los demás $(54,11 \%)$, seguido por los residuos no peligrosos aprovechables - UNHW (41,53 \%) y los chemical and pharmaceutical waste - CPW $(4,37 \%)$.

Conclusión: La entidad cumple con las principales exigencias del gobierno nacional, identificando buenas prácticas de aprovechamiento y bioseguridad; bajo el diagnóstico, es posible la implementación de las directrices emanadas por la investigación para optimizar los procedimientos. 
Originalidad: Se observaron los lineamientos y actividades para la separación, aprovechamiento y recolección interna de residuos dentro de una IPHS; interrelacionándolos con los servicios prestados y sus recursos. Este trabajo podría ser una guía para instituciones afines.

Limitaciones: El artículo se centra en la gestión interna y no externa de MW.

Palabras Clave: Residuos hospitalarios - MW, gestión de residuos peligrosos, bioseguridad, institución prestadora de servicios hospitalarios o de salud - IPHS, residuos de fármacos y biosanitarios - HCW, urban solid waste - USW.

\section{Resumo}

Introdução: 0 artigo apresenta os resultados da pesquisa realizada de janeiro de 2018 a dezembro de 2019, em uma instituição prestadora de serviços de saúde de terceiro nível (IPHS), localizada em Tunja (Boyacá), leste da Colômbia central.

Problema: Existem várias dificuldades relacionadas ao gerenciamento dos resíduos produzidos pelo IPHS; Práticas irresponsáveis causam a disseminação de infecções que repercutem em situações críticas local, regional ou internacionalmente.

Objetivo: Avaliar o gerenciamento de resíduos hospitalares e afins (HCWM), realizado por um IPHS, e formular estratégias para seu aprimoramento.

Metodologia: A pesquisa foi realizada em três (3) etapas: Coleta de informações (por meio de inspeções e pesagem de resíduos); análise de dados (desde a qualificação e quantificação dos resíduos); Por fim, foram propostas algumas diretrizes para seu gerenciamento adequado, com base no contexto da organização.

Resultados: O IPHS gerou 397,6 toneladas de resíduos hospitalares e similares (MW). Enquanto os resíduos de risco biológico (PN) predominaram sobre os demais (54,11\%), seguidos pelos resíduos não perigosos utilizáveis - UNHW (41,53\%) e resíduos químicos e farmacêuticos - CPW $(4,37 \%)$.

Conclusão: A entidade atende aos principais requisitos do governo nacional, identificando boas práticas de utilização e biossegurança; No diagnóstico, é possível a implementação de diretrizes emanadas de pesquisas para otimizar procedimentos.

Originalidade: Foram observadas as diretrizes e atividades para a separação, uso e coleta interna de resíduos em um IPHS; inter-relacionando-os com os serviços prestados e seus recursos. Este trabalho pode ser um guia para instituições relacionadas.

Limitações: 0 artigo enfoca o gerenciamento interno e não externo de MW.

Palavras-chave: Resíduos hospitalares - MW, gerenciamento de resíduos perigosos, biossegurança, instituição hospitalar ou prestadora de serviços de saúde - IPHS, medicamentos e resíduos biossanitários - HCW, resíduos sólidos urbanos - USW.

\section{INTRODUCTION}

$\mathrm{MW}$ is a special type of hazardous waste. Its definition can vary significantly between countries; some refer to these as sanitary waste ( $\mathrm{HCW}$ ) and others as medical waste (MW). As indicated by C. Ramírez and E. Gonzalez [1], MW is the waste generated by healthcare activities, which can include a wide range of materials, including: needles, 
used syringes, dirty bandages, human tissues, diagnostic samples, blood, chemical and pharmaceutical products, medical devices and radioactive materials.

In Colombia, the Ministry of Health and Social Protection refers to MW as: "residue or waste with biological or infectious risk", considering them dangerous when they contain "pathogens such as microorganisms and other agents with sufficient virulence and concentration to cause diseases in humans or animals" [2]. While the Ministry of the Environment and Health defines them as: "solid, liquid or gaseous substances, materials or by-products, generated by a productive task, resulting from the activity carried out by the generator" [3]. Some examples of generators described by this government entity are: facilities or institutions related to the provision of hospital or health services (IPHS), teaching, research with living organisms and corpses, cemeteries, morgues, funeral homes, pharmacies, pigmentation centers, veterinary clinics, zoonoses centers, zoos, pharmaceutical laboratories and the production of medical devices, among others [3].

According to S. Çalıs and B. Arkan, every year, 5.2 million people (among them, four million children under the age of five) die from pathologies caused by inadequate waste management [4]. Other harmful impacts were described by L. Rushton in 2003, highlighting: the high incidence of underweight newborns, the appearance of various congenital malformations, and to a lesser extent, the appearance of some types of cancer [5]. Due to this situation, in recent years, the characteristics and particular origin of this type of waste, have generated a great concern worldwide, especially regarding the optimization of its management, since otherwise, $\mathrm{MW}$, as indicated by the World Health Organization (WHO) [6] and E. S. Windfeld and M. S. L. Brooks [7], will continue to represent significant potential risks to health and the environment, and may even cause, according to P. D. Eagan and E. Joeres, secondary contamination by dioxins and other chemical substances [8].

Faced with this situation, the need to draw up an HCWM system, in accordance with the anticipated needs (quantity and quality of waste), and the social, economic, environmental and legal reality of the country, is pressing. Thus, HCWM can be a pillar safeguarding the health of workers and the nearby population, becoming in turn a means of promotion for the protection of the environment. Therefore, the methodology first characterized MW; reviewing in parallel, biosecurity and management criteria, which allowed for the development of the entity's environmental and health diagnosis. Subsequently guidelines were proposed with which this and other IPHS could base activities related to the internal management of $\mathrm{MW}$. All of this is based on parameters set forth in Decree 780 of 2016 of the Ministry of Health and Social Protection and Resolution number 1164 of 2002, issued by the Ministry of Environment and Health. 


\subsection{LITERATURE REVIEW}

In the past, as described by Y. C. Jang et. al., MW was often mixed with urban solid waste USW, in some cases out of ignorance, and in others, due to an underestimation of its highly dangerous nature, to be later disposed of in landfills [9], bringing with it a variety of problems, effects on the environment and, consequently, on humans. For this reason, in recent years, environmental and parliamentary organizations have made permanent efforts to delimit the process of proper management and final disposal of MW, implanting a growing interest and obligation in IPHS regarding its efficient management.

In this context, some researchers recommend various methods for the adequate or alternative management of solid waste, pointing, for example, to standardized management systems (A. Simon et al.) [10], categorical impact groups (A. Carvalho et al.) [11], environmental management accounting (K. G. Papaspyropoulos et al.) [12], use of eco-stations displaying appropriate environmental education (C. R. Malaver Flor et al.) [13] and life cycle analysis (S. Bersimis and D. Georgakellos) [14]. However, due to the high danger they pose and the special management characteristics they demand, MW prevents these techniques from being widely used, as they could cause contamination of the UNHW, turning the latter into infectious and toxic waste (Y. C. Jang et al.) [9]. Thus, as P. D. Eagan and E. Joeres explain, it is relevant that waste management is constantly verified and, if possible, the limitations found in each case are identified and modified [8].

Other researchers have analyzed the technologies available for the treatment of MW. For example, M. K. Ghasemi and R. B. M. Yusuff [15], summarize the treatment methods available in Malaysia, describing the advantages and disadvantages of their application; C. Jiang et al. [16], specify the need to update and optimize waste incineration plants; and B. K. Lee et al. [17], present some alternatives for the treatment of $\mathrm{MW}$, in order to reduce costs for its elimination.

Meanwhile, Y. Chen et al., focus on the importance of source classification and reduction, indicating that these measures can significantly prevent dioxin and furan emissions [18]; while L. Liberti et al. [19], present an optimization methodology of the HCWM system for hospitals in Italy; J. I. Blenkharn [20], summarizes the UK HCWM standards; C. E. Da Silva et al. [21] and J. I. Blenkharn [22] discuss HCWM in southern Brazil, but the latter exposes and analyzes the reasons why it is so complex for remote communities in developing countries to have access to the new alternatives that technology offers.

Likewise, according to D. Komilis et al., studies have been carried out during the last decades to thoroughly investigate the rates of generation and composition of 
MW in health care activities [23]. For example, M. H. Dehghani et al. [24], analyze the qualitative and quantitative characteristics of MW, proposing comprehensive management solutions based on their particularities; while E. N. Korkut [25] proposes a new approach for estimating future amounts of MW.

Parallel to these investigations, J. Hong et al. [26], propose a model for the environmental and economic assessment of the HCWM life cycle, which could implicitly reduce harmful impacts and costs for IPHS. Another HCWM-oriented environmental assessment model is described by M. Zamparas et al. [27], who make a series of recommendations for the integrated management of $\mathrm{HCW}$, evaluating among other aspects: the applicable legislation, the contribution of HCW from a social and economic perspective, as well as the available management procedures and methods in Greece. Likewise, M. M. A. El-salam, performs an environmental analysis of the management process, which not only indicates the relevance of adequate segregation at the source, but also exemplifies the possible consequences of little or no training of human resources, with respect to adequate separation at the source [28].

In turn, M. Chaerul et al. [29], explains the transcendental role that hospital or IPHS administration has in relation to the treatment of infectious waste (HWPC), before its final disposal, and proposes an HCWM model based on the dynamics of the institution to determine the interaction between system factors, through the use of software, demonstrating that informatics can be applied to this process and providing an insight into its future systematization; both in terms of MW management and health promotion and prevention, as expressed by A. Serrano Santoyo et al., who use Teleepidemiology to try and harness the potential of e-health in favor of social development [30]. However, advanced technology, aimed at the safe disposal of these wastes, is expensive, complex and difficult to access for most IPHS in developing countries, as suggested by J. I. Blenkharn [22], therefore, it is essential that these institutions formulate management techniques according to their financial scope, always keeping in mind a sustainable approach.

\section{METHODOLOGY}

The HCWM diagnosis only took into account internal management, that is, the management of MW within the institution. This project was developed in three (3) stages: 1) information gathering phase; 2) data analysis; and 3) establishment of alternative management proposals and recommendations, taking into account the results obtained and the particular characteristics of the organization. 
In order to achieve the objectives outlined in a practical and contextualized manner, all the activities carried out took into account the applicable regulations and the control measures established by the Colombian government.

\subsection{CAPTURE AND COLLECTION OF INFORMATION}

In order to carry out this phase, in each of the identified MW generating subsections or sources, various aspects were first evaluated through empirical formats, taking as a reference those established by the Ministry of Health and Social Protection [2], the Ministry of the Environment and Health [3], WHO [6] and M. K. Ghasemi and R. B. M. Yusuff [15]. Among others, the following were assessed: state of the facilities, biosafety conditions, emergency exits, state of hydrants; as well as the activities carried out by human resources, in order to understand their magnitude and their impact on the rate of generation of certain types of waste. Similarly, an evaluation of the characteristics related to the collection and segregation of waste was carried out, paying special attention to the intermediate storage rooms, the collection routes and schedules, and the characteristics of the vehicles used for this purpose.

Taking into account the classification, handling and management of waste, described by the WHO [6] and M. H. Dehghani et al. [24], the characteristics of this type of waste presented by M. K. Ghasemi and R. B. M. Yusuff [15], and the applicable Colombian legislation, presented by the Ministry of Health and Social Protection [2] and the Ministry of the Environment and Health [3], objective evaluation patterns were built, which, through empirical formats and guides established by the authors (recognizing a measurable analysis around the legal compliance of the institution), implemented periodic inspections, gathering photographs and records, thus compiling the daily weight and the qualitative characteristics of the waste over a two-year period (January 2018 to December 2019).

Finally, to determine the basic behavior of flows discharged by the institution, two points were gauged for 24 hours; one, collecting the sewage from the southern sector of the hospital, and the other, collecting those from the northern sector. Likewise, under the careful chain of custody protocol, water samples were subsequently sent to an external laboratory (certified by the Institute of Hydrology, Meteorology and Environmental Studies of Colombia - IDEAM), observing the procedures described by the United States Environmental Protection Agency (US EPA) [31], D. Duncan et al. [32], A. Peña-Álvarez and A. Castillo-Alanís [33]. 
Diagnosis Of Hospital, Hazardous and Similar Waste Management of an Institution Providing Health Services - IPHS

\subsection{DATA ANALYSIS}

After data collection, mainly as a result of the daily weighing of the waste, graphs were obtained showing their behavior on a monthly average. In this way, it was possible to obtain a percentage and magnitude (weight) estimate of waste segregation; its generation capacity in $\mathrm{kg}$ hospital bed ${ }^{-1}$ day $^{-1}$, since, as stated by L. Liberti et al. [19], the number of beds in service is strongly related to the quantity of HCW produced (when compared with the capacity of other entities) and the production rate of UNHW, BW and CPW.

On the other hand, the periodic inspections, observation and exhaustive registration in empirical formats, of all the containers where solid and liquid waste is distributed (including not only waste bins or harvester guardians of Sharps, but also some that are not specified in the legislation, but that play a fundamental role in the management process, such as drums or hedpacks), allowed for the evaluation of the processes and procedures related to the segregation and management of MW, as well as their physical qualities, for consistent characterization. In the same way, the existing containers were qualified and quantified, determining the number of containers that do not comply with Colombian regulations.

\subsection{ESTABLISHMENT OF ALTERNATIVE PROPOSALS FOR EFFECTIVE INTERNAL MW MANAGEMENT}

This phase is transcendental, as indicated by the WHO [6], the protection of MW within health care facilities should be a priority, since diseases caused by improper handling of MW originate more frequently at the site of generation; in addition, an incorrect segregation of these can trigger a higher cost because of the treatment or final disposal, as pointed out by B. K. Lee et al. [17] and J. I. Blenkharn [20], showing for example that in the United States, getting rid of 1 kilogram $(\mathrm{kg})$ of MW costs USD \$ 0.79, and in the United Kingdom around $£ 0.45$, which contrasts sharply with the elimination of HWPC, with a value of USD \$ 0.12 per $\mathrm{kg}$. In Colombia this amount can exceed COP \$ 3000, which is equivalent to approximately USD \$ 0.8, in May 2020.

With these considerations, based on the diagnosis made and the shortcomings identified, new guidelines and strategies were defined that could generate greater efficiency in the HCWM. In this stage, potentially usable by-products are specified, the type of containers to be used, assignment of responsibilities to the personnel involved in the management chain, among other aspects of special interest. Subsequently, good biosecurity practices were proposed, based, among other aspects, on the threats found. 


\section{RESULTS}

\subsection{INITIAL SANITARY, ENVIRONMENTAL AND BIOSAFETY DIAGNOSIS}

The third level IPHS (medium-large size in Colombia) was determined to serve a geographic area where 114,000 to 195,000 inhabitants live, according to C. Binder et al. [34] and I. Sanchez et al. [35], respectively; with around 300 beds to care for patients with multiple diseases, from the simplest to the most difficult to treat. In addition to the above, and taking into account that hospitals represent one of the most complex types of organization, whether for its critical service or for the many highly qualified people, materials, suppliers and skills required to provide that service, such as described by R. Rijo et al. [36], it follows that the institution evaluated is highly complex, but medium capacity by Colombian standards, according to the classification shown by J. D. Moreno R. [37]. In addition, several sources or subsections were determined, generating MW and UNHW; these are described in Table 1.

Table 1. Distribution of MW generation sources in the IPHS.

\begin{tabular}{|c|c|c|}
\hline Floors of building & $\begin{array}{l}\text { Subsections or MW generating } \\
\text { sources identified }\end{array}$ & $\begin{array}{l}\text { UNHW generating Subsections } \\
\text { or Sources Identified }\end{array}$ \\
\hline Basement (level 1) & Pathology laboratory, morgue. & $\begin{array}{l}\text { Biomedical engineering, environmental } \\
\text { engineering, maintenance workshop; wa- } \\
\text { rehouse and supplies office; general file. }\end{array}$ \\
\hline Ground floor & $\begin{array}{l}\text { Emergencies, clinical laboratory, } \\
\text { radiology and diagnostic images, } \\
\text { outpatient, pharmacy, cardiology, } \\
\text { rehabilitation. }\end{array}$ & $\begin{array}{l}\text { Kitchen, cafeteria, administrative offices } \\
\text { (management, human talent, others), } \\
\text { waiting rooms for users, among others. }\end{array}$ \\
\hline First floor (1st) & $\begin{array}{l}\text { Surgery rooms, neonatal intensive } \\
\text { care unit (NICU), gastroenterology, } \\
\text { gynecology and delivery room. }\end{array}$ & Billing offices and administrative areas. \\
\hline Second floor (2nd) & Pediatrics. & $\begin{array}{l}\text { Lactario, billing offices and administrative } \\
\text { areas, medical hospitalization area. }\end{array}$ \\
\hline Third floor (3rd) & Adult intensive care unit (AICU). & AICU coordination and billing office. \\
\hline Fourth floor (4th) & $\begin{array}{l}\text { Neurosurgery and specialties } \\
\text { (Nephrology, urology, neurology, } \\
\text { among others), orthopedics. }\end{array}$ & $\begin{array}{l}\text { Coordination of epidemiology, billing and } \\
\text { administrative offices. }\end{array}$ \\
\hline Fifth floor (5th) & Internal Medicine. & $\begin{array}{l}\text { Billing and administrative offices (deputy } \\
\text { management, others). }\end{array}$ \\
\hline Sixth floor (6th) & $\begin{array}{l}\text { General surgery, pediatric intensive } \\
\text { care unit (PICU). }\end{array}$ & $\begin{array}{l}\text { Billing and administrative offices (nursing } \\
\text { coordination, others). }\end{array}$ \\
\hline
\end{tabular}

Source: own work. 
Likewise, it was established that all services have very good lighting and ventilation, generally two independent and opposite emergency exits; with hydrants and fire extinguishers in good condition and with remaining lifespan, located in various areas of the evaluated subsections. In general, no inconsistency related to inappropriate biosecurity practices of health personnel was perceived throughout the building.

It was evidenced that within the IPHS, two waste collection routes are carried out per day. The first one starts at 6 a.m. and ends at 7a.m. and the other one begins at 4 p.m. and ends at approximately 5 p.m.; consistent with the low circulation of users at those hours of the day. Likewise, it was possible to identify the use of three vehicles per floor, for the transport of solid waste, compliant with the color code defined by the Ministry of Health and Social Protection [2] and the Ministry of Environment and Health [3], that is, two per floor in the case of gray and green (recyclable and organic waste, UNHW), and one vehicle per service, for the code red (MW), which could help prevent infectious crossing.

The institution has defined some intermediate storage rooms and central storage for hazardous and non-hazardous waste, identified through the color code defined by the Ministry of Health and Social Protection [2] and the Ministry of Environment and Health [3]. Unfortunately, the former are shared among several of the generating subsections or sources in each plant, which could lead to an infectious crossing; while in the second case, it was established that there are adequate conditions to preserve the MW without any risk for the users and the personnel who manipulate and dispose of them. However, the central storage rooms for ordinary and recyclable waste are moderately overrun by the amount of waste deposited, without demonstrating a defined organization. Regular cleaning and disinfection of these rooms stand out, as well as adequate signage in most, favoring the mandatory use of personal protective equipment (PPE).

\subsection{QUALIFICATION OF THE MW GENERATED AND EVALUATION OF THE CONTAINERS USED FOR SEGREGATION}

The entity generates recyclable waste - RW (from whey bags, plastic bottles, cardboard, paper, etc.), which is expected to be disposed of in the gray container; along with organic or common waste - OW (dust, Styrofoam, wax paper, organic waste originating from uncontaminated food, etc.). Likewise, in the green container; biosanitary waste - BSW (gauze contaminated with body fluids, probes, dressings, etc.). The red container, or guardian collector in the case of sharps (SMW), such as hypodermic 
needles contained: pathological waste - PAW (biopsies, amputation remains, placentas, fetal deaths, etc.), various containers such as the secretion aspirator bottles or buckets depending on their size and particular characteristics, CPW (reagents, cytotoxic, expired or remaining drugs, etc.), plastic containers or bottles similar to hedpacks, gallons or drums. Furthermore, it was observed that no radioactive waste is generated - RW. On the other hand, Table 2 presents the synthesis of the results obtained regarding the assessment of all the containers used for the segregation of MW inside the hospital.

Table 2. Final assessment of legal compliance with Resolutions 780 of 2016 and 1164 of 2002, with respect to the containers used for waste segregation.

\begin{tabular}{ccccc}
\hline $\begin{array}{c}\text { Type or color } \\
\text { of the waste } \\
\text { container }\end{array}$ & $\begin{array}{c}\text { Total number } \\
\text { of containers in } \\
\text { the institution }\end{array}$ & $\begin{array}{c}\text { Number of } \\
\text { containers that do } \\
\text { not comply with } \\
\text { the legislation }\end{array}$ & $\begin{array}{c}\text { Final balance of } \\
\text { compliance (\%) }\end{array}$ & $\begin{array}{c}\text { Number of } \\
\text { containers } \\
\text { requiring change } \\
\text { or repair }\end{array}$ \\
\hline Green & 511 & 62 & 87.87 & 17 \\
\hline Gray & 251 & 7 & 97.22 & 4 \\
\hline Red & 428 & 36 & 91.59 & 17 \\
\hline $\begin{array}{c}\text { Guardian } \\
\text { collectorsharps }\end{array}$ & 135 & 20 & 85.19 & N.A. \\
\hline $\begin{array}{c}\text { Hedpack, gallon } \\
\text { or drum }\end{array}$ & 41 & 0 & 100 & N.A. \\
\hline $\begin{array}{c}\text { Bucket } \\
\text { Laboratory } \\
\text { plastic bucket }\end{array}$ & 14 & 0 & 100 & N.A. \\
\hline \begin{tabular}{c} 
Metal container \\
\hline
\end{tabular} & 2 & 0 & 100 & N.A. \\
\hline
\end{tabular}

Source: own work.

\subsection{QUANTIFICATION OF THE WASTE GENERATED}

Figures 1 and 2 show a percentage and magnitude (weight), estimate of waste segregated within the IPHS during the period evaluated; while Figures 3, 4, 5 and 6 present the results obtained with respect to the behavior (production), of all MW, showing the monthly average generated in each case; also, the segregation of BW, UNHW, and CPW in the period of time analyzed. Likewise, the generation capacity of these wastes is presented in Table 3. 
Diagnosis Of Hospital, Hazardous and Similar Waste Management of an Institution Providing Health Services - IPHS

Table 3. Estimated waste generation capacity in kilograms per bed per day.

\begin{tabular}{|c|c|c|}
\hline & Waste category & $\begin{array}{c}\text { Generation capacity } \\
\left(\mathrm{kg} \mathrm{hospital} \mathrm{bed}^{-1} \text { day }^{-1}\right)\end{array}$ \\
\hline Total medical waste (MW) & & 1.82 \\
\hline \multirow[t]{4}{*}{ Biohazard waste (BW) } & & 0.98 \\
\hline & Biosanitary waste (BSW) & 0.80 \\
\hline & Pathological waste (PAW) & 0.17 \\
\hline & Sharps medical waste (SMW) & 0.01 \\
\hline \multicolumn{2}{|c|}{ Usable non-hazardous waste (UNHW) } & 0.75 \\
\hline & Inert, ordinary and biodegradable waste (OW) & 0.57 \\
\hline & Plastic waste (PW) & 0.11 \\
\hline & Glass waste and others & 0.04 \\
\hline & Paper and paperboard & 0.03 \\
\hline \multicolumn{2}{|c|}{ Chemical and pharmaceutical waste (CPW) } & 0.08 \\
\hline & Reactive waste and others & 0.04 \\
\hline & Drug and cytotoxic residues & 0.03 \\
\hline & Waste from used oils & 0.01 \\
\hline & Wastes containing heavy metals & 0.0009 \\
\hline & Pressurized waste & 0.0001 \\
\hline
\end{tabular}

Source: own work. 
Medical waste (MW)
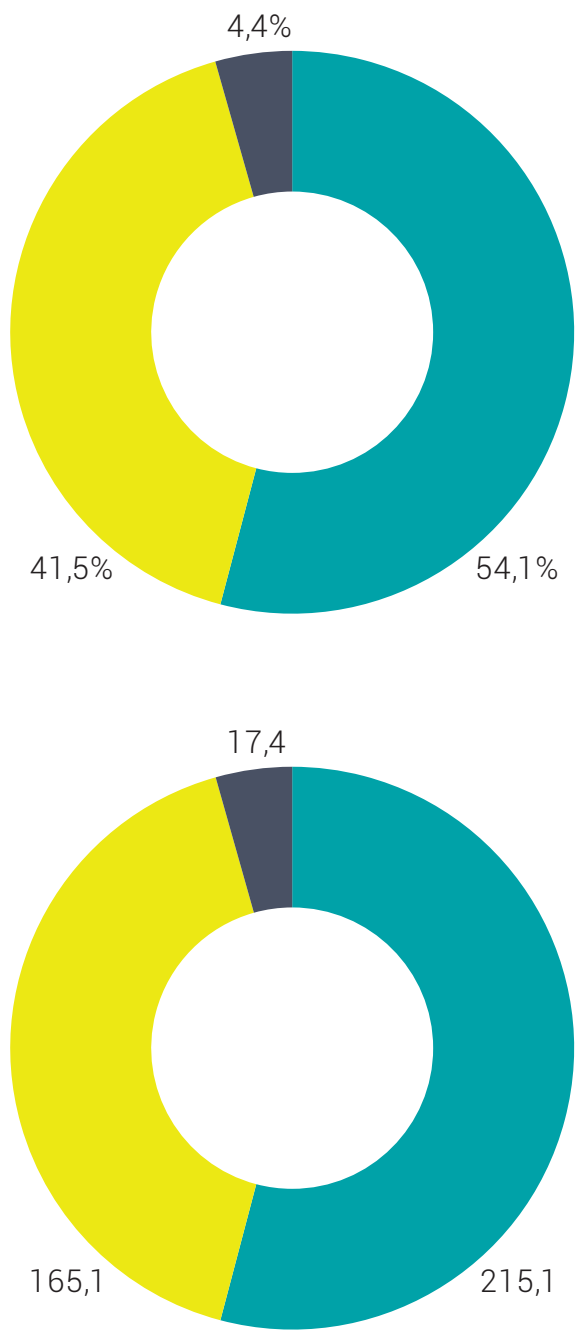

Biohazard waste

Usable non-hazardous waste

Chemical and pharmaceutical waste

Total 397.6 tons of MW
Biohazard waste (BW)
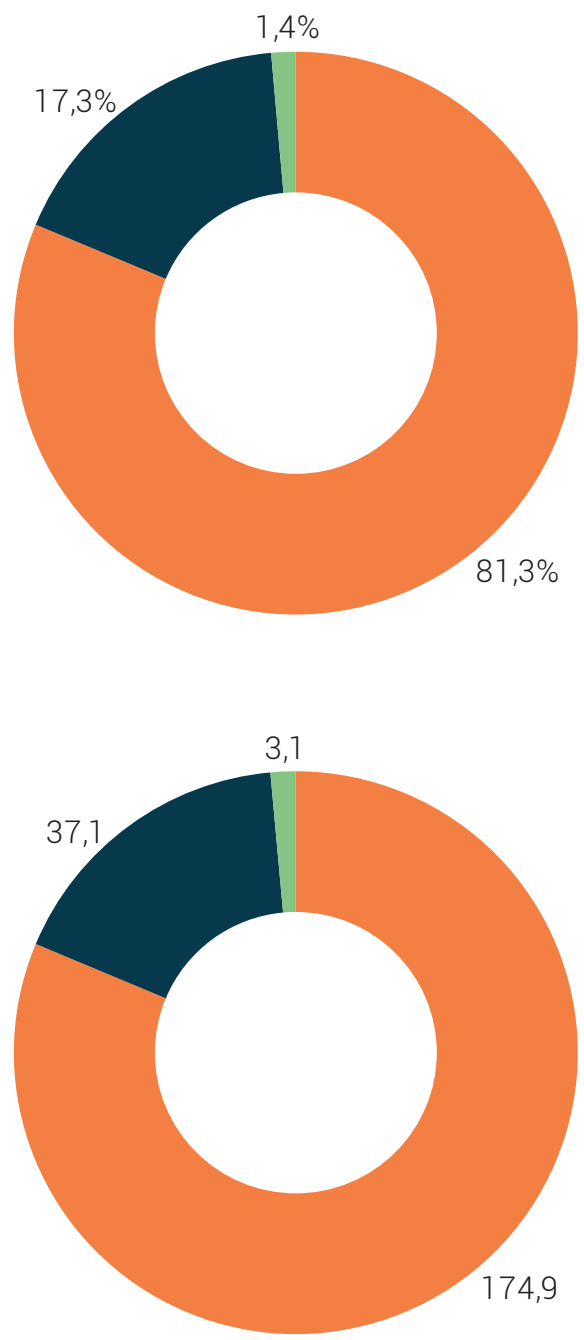

Biosanitary waste

Pathological waste

Sharp medical waste

Total 215.1 tons of BW

Figure 1. Percentage estimate -\% (above), and in magnitude - weight in tons (below), of the MW and BW generated within the IPHS during the evaluated period (January 2018 to December 2019).

Source: own work. 
Usable non-hazardous waste (UNHW)
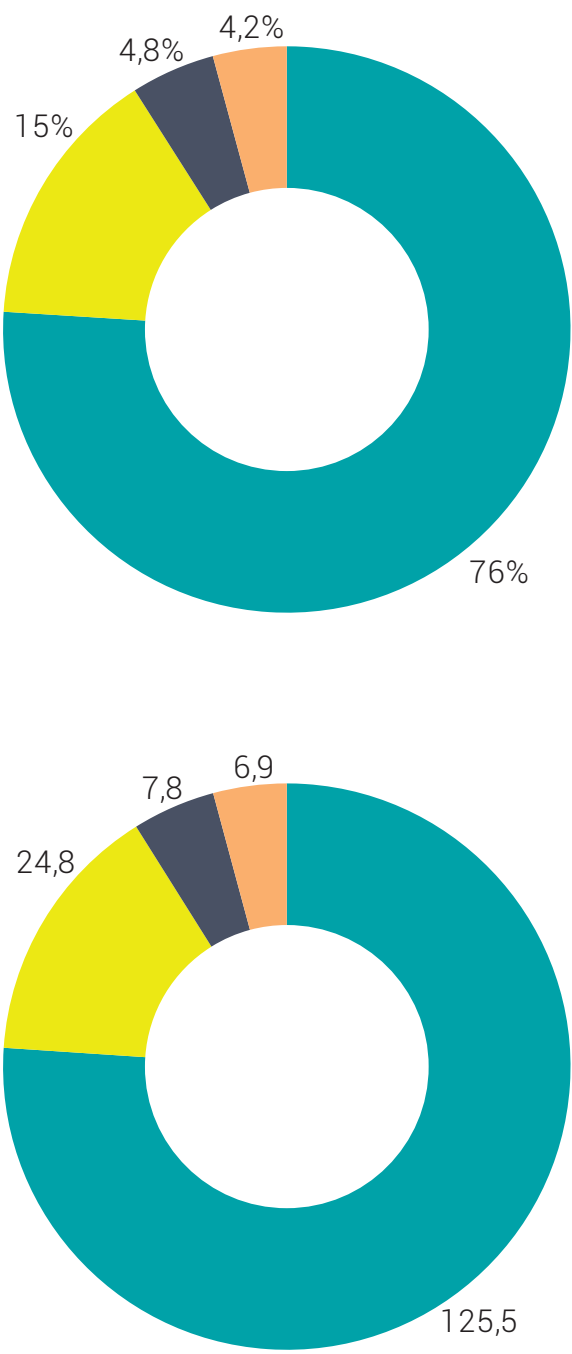

Inert, ordinary and biodegradable waste

Plastic waste

Glass waste and others

Paper and paperboard

Total 165.1 tons of UNHW
Chemical and pharmaceutical waste (CPW)
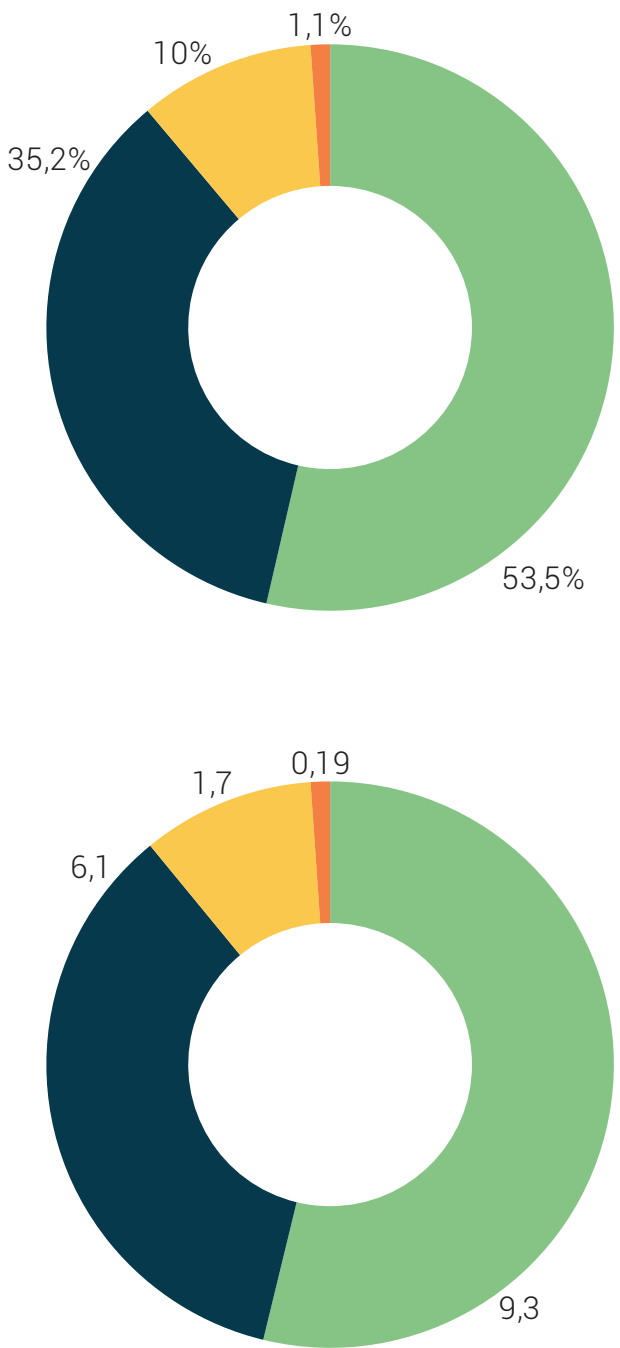

Reactive waste and others

Drugand cytotoxic residues

Waste from used oils

Wastes containing heavy metals

Total 17.3 tons of CPW

Figure 2. Percentage estimate -\% (above), and in magnitude - weight in tons (below), of the UNHW and CPW generated within the IPHS during the evaluated period (January 2018 to December 2019).

Source: own work. 

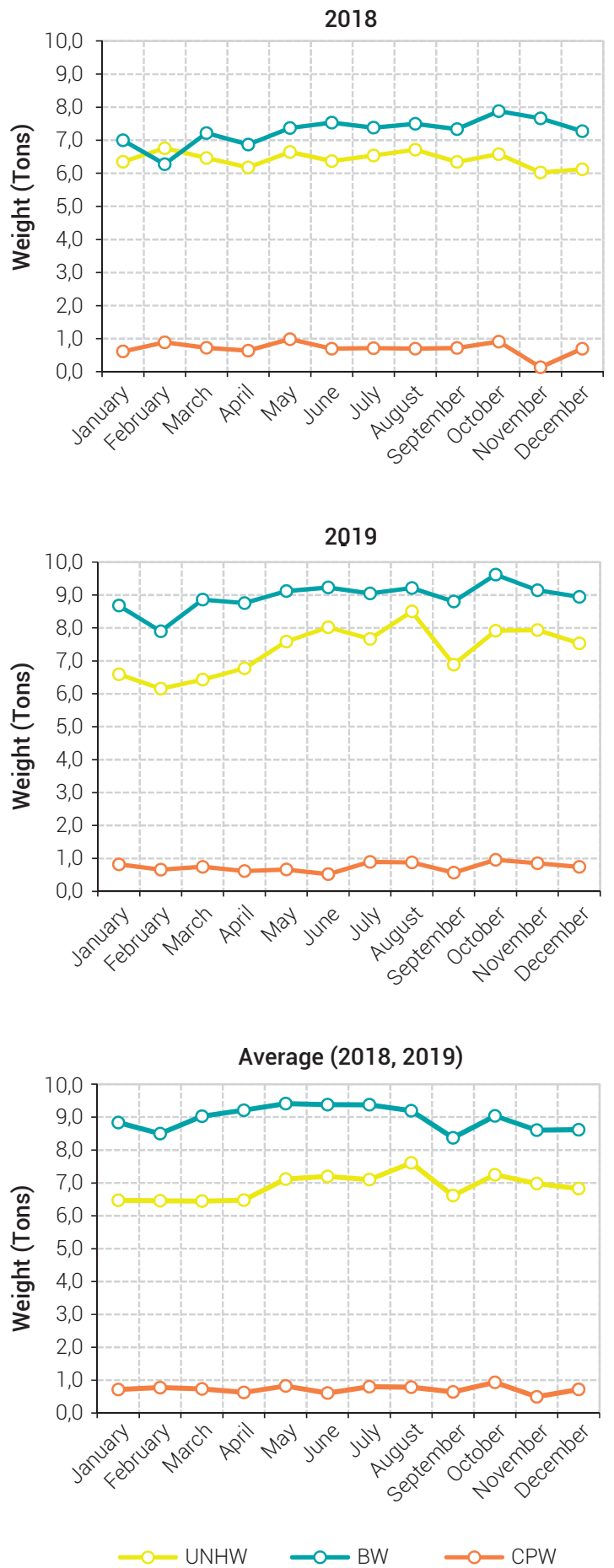

Figure 3. Monthly generation, annual MW behavior, and average data during the period analyzed.

Source: own work. 

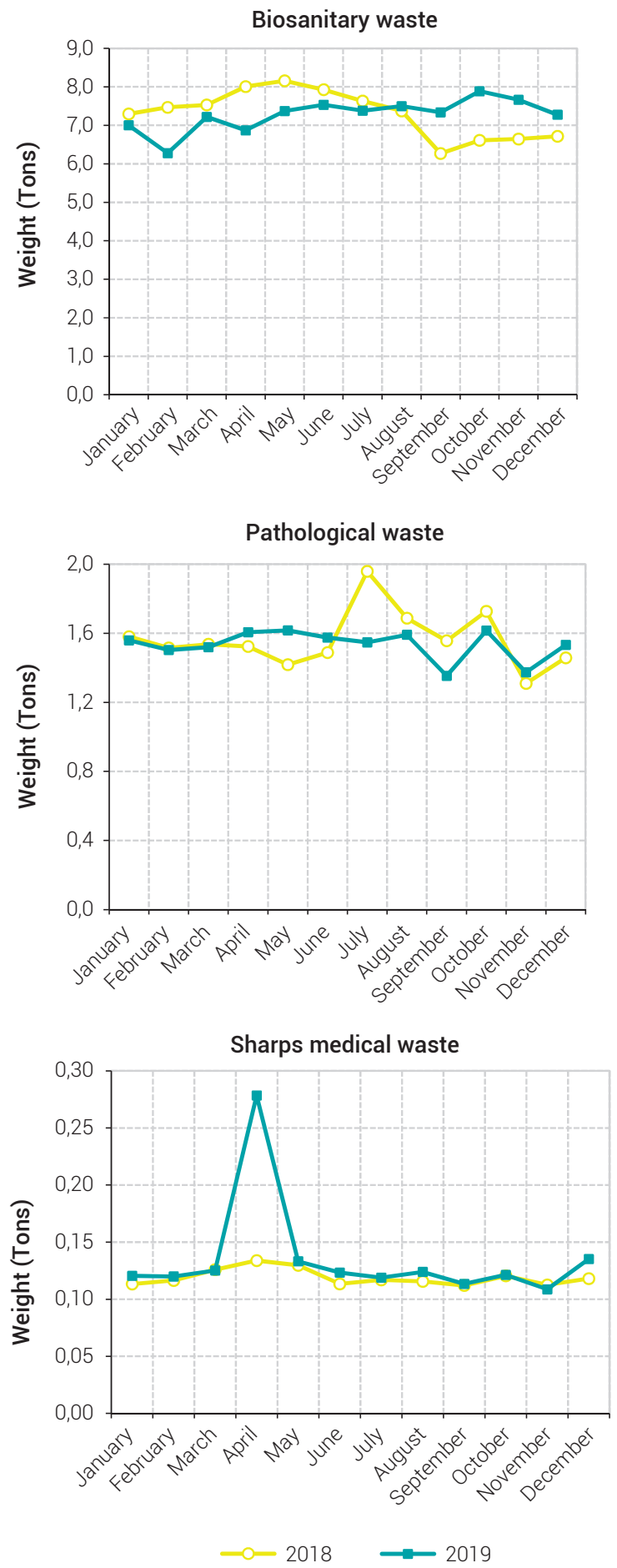

Figure 4. Monthly generation and annual behavior of BW. The scale varies according to your production.

Source: own work. 

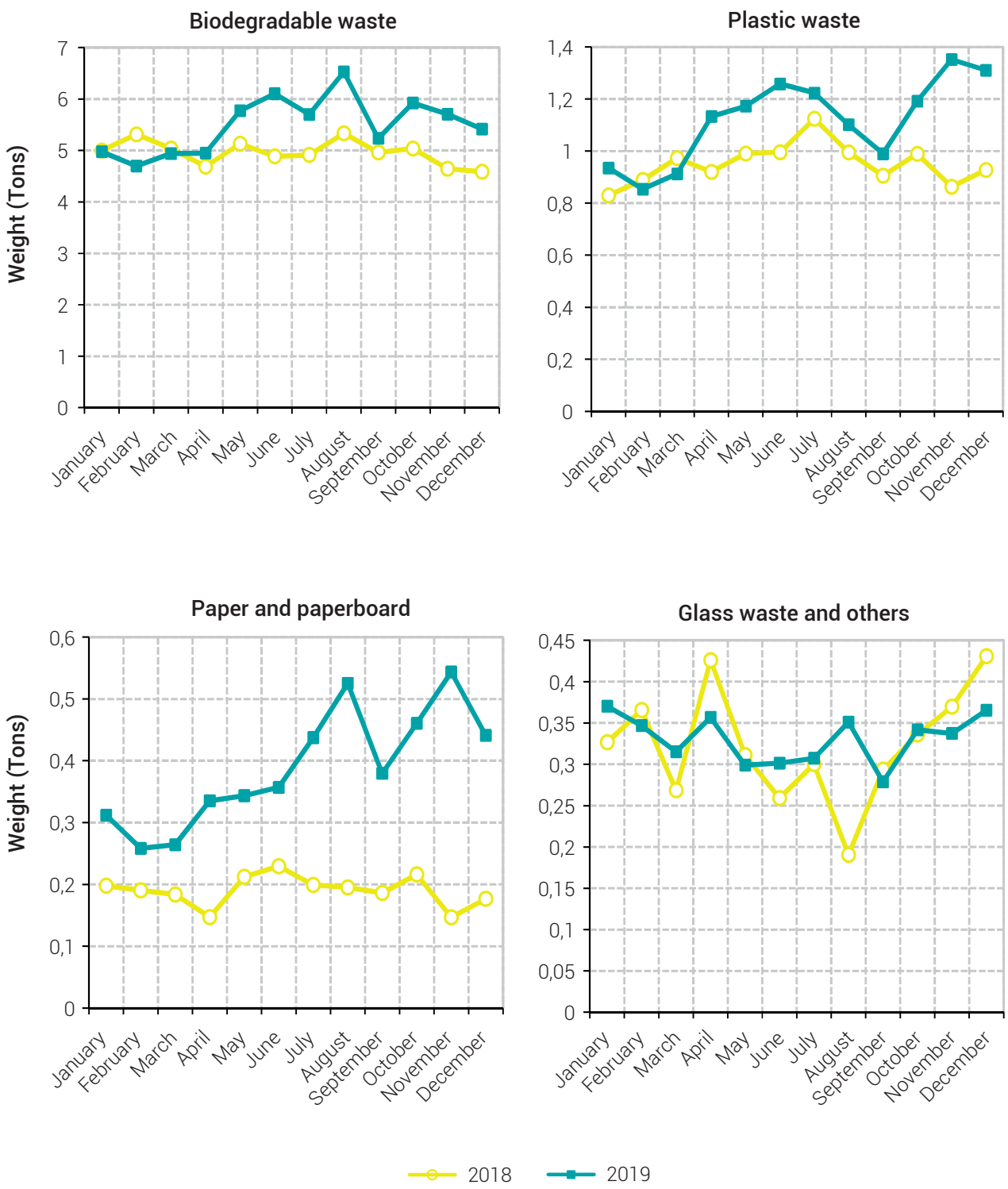

Figure 5. Monthly generation and annual behavior of UNHW. The scale varies according to your production.

Source: own work. 

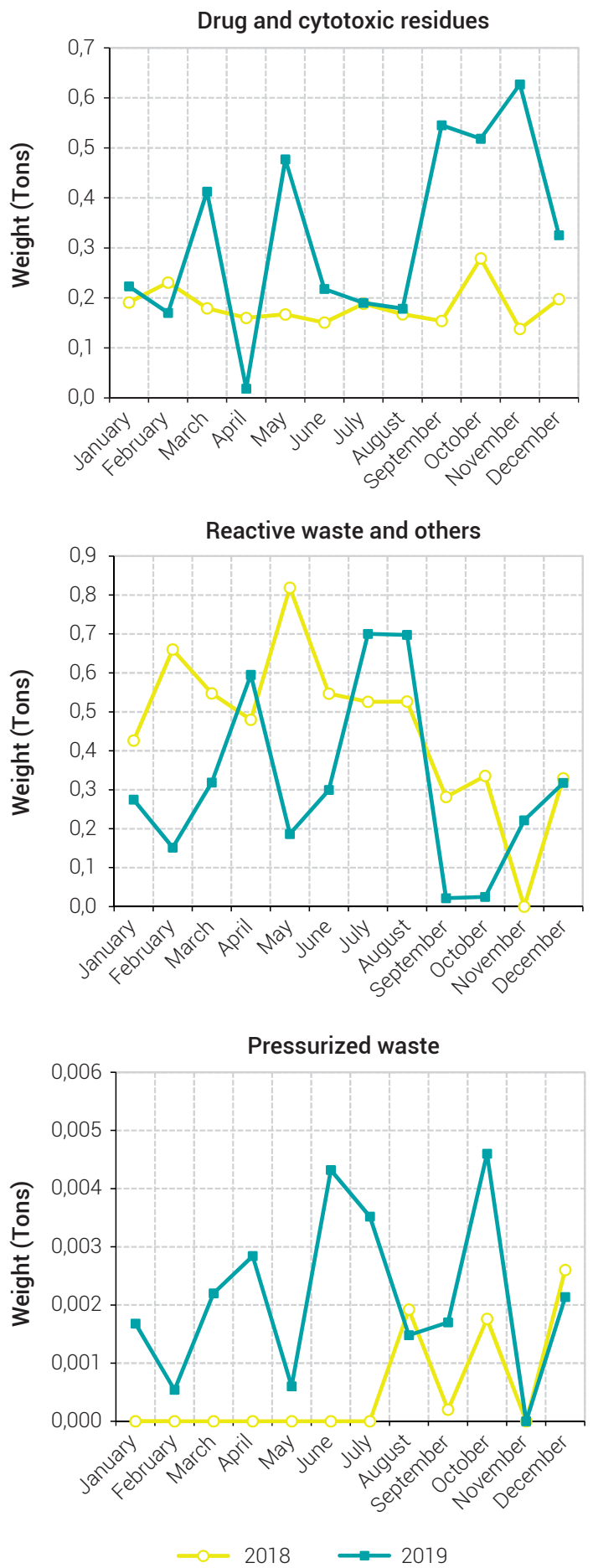

Figure 6. Monthly generation and annual behavior of CPW. The scale varies according to your production.

Source: own work. 


\subsection{DUMP EVALUATION (WASTE WATER)}

Through the capacity and data capture, it was possible to establish the flow curve, the average flow discharged, the average maximum and minimum flow discharged in two sectors of the entity; one to the North and the other one to the South. These results are presented by means of Figure 7, shown below.

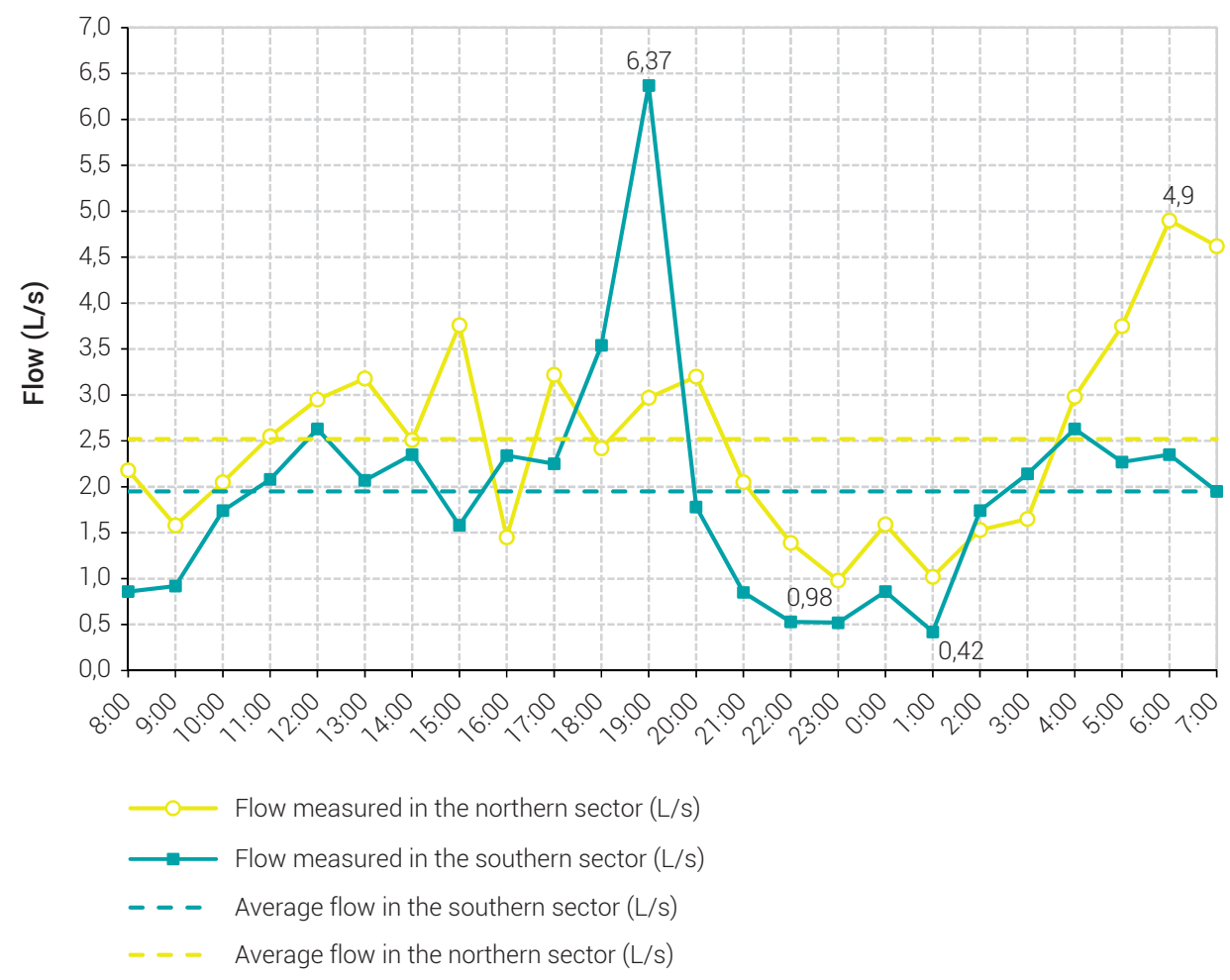

Figure 7. Behavior of the flows measured during 24 hours, on May 19 and 20, 2019, in two sectors of the IPHS; one in the north and the other in the south.

Source: own work.

\section{DISCUSSION, CONCLUSIONS AND RECOMMENDATIONS FOR IPHS}

The behavior of wastewater measured in the sectors shows dynamic variations over the 24-hour period, possibly related to the activities carried out in each sector of the entity. The flow of the southern sector presented a minimum of $0.42 \mathrm{Ls}^{-1}$ at midnight, which increases as dawn progresses, reaching an intermediate peak at the zenith, showing a maximum of $6.37 \mathrm{Ls}^{-1}$ at 19 hours, gradually falling from that time onwards. Similarly, in the northern sector a minimum of $0.98 \mathrm{Ls}^{-1}$ was evident near midnight, 
with initial difficulty, it begins to increase progressively as the morning progresses until reaching a maximum limit of $4.9 \mathrm{Ls}^{-1}$ in the first hours in the morning (6 hours), later declining and maintaining a similar and discontinuous behavior to that of the southern sector, but with higher flows, feasible from comparing the flow averages, which report a little more than $0,5 \mathrm{Ls}^{-1}$ more for the northern sector $\left(2.52 \mathrm{Ls}^{-1}\right)$, than for the southern $\left(1.95 \mathrm{Ls}^{-1}\right)$.

These results indicate that the highest residual water discharges in the IPHS occur in the morning hours in the northern sector, as a result of carrying out multiple activities that require abundant water (subsequently eliminated through the institution's hydraulic-sanitary system), such as hygiene and patient showering, cleaning and disinfection of areas, use of bathrooms with greater flow of people, among others. Here, the residual water from the hospitalization area converges, and after noon until dusk in the southern sector, where flow from the emergency and radiology services converge, at a moment when, usually, a high number of people attend.

If the average flow measured in the sectors is taken as constant, the volume of waste water discharged on average over a year can be theoretically established; from this point of view, the entity theoretically discharges, through the sewage pipeline from the southern sector, around $61495.2 \mathrm{~m}^{3} \mathrm{year}^{-1}$ into the municipal sewer, and from the northern sector, approximately $79470.72 \mathrm{~m}^{3} \mathrm{year}^{-1}$, that is, the IPHS possibly discharges around $140965.92 \mathrm{~m}^{3} \mathrm{year}^{-1}$, the equivalent of a volume occupied by 56 Olympic pools. For this reason, it is recommended that this IPHS and its analogues study the technical-economic possibility of building a plant for the treatment of residual water; but first, the water discharged by the IPHS must be physicochemically and microbiologically characterized.

On the other hand, the quantification and careful observation of existing recipients and those that do not comply with Colombian regulations, show a positive balance, taking into account the size and complexity of the processes carried out within the IPHS, with a level of compliance greater than $85 \%$. The synthesis of these results is presented in Table 2.

Since the processes and procedures related to biosecurity are adequate, and they abide by the regulations established by the national government, particularly by the Ministry of Health and Social Protection [2] and the Ministry of Environment and Health [3], the IPHS could continue to use the materials and equipment used so far for the correct segregation, storage and disposal of $\mathrm{MW}$. The only recommendation is to tag some containers with international symbols that allow for the easy identification of the waste that should be deposited inside; this could mean greater efficiency in the 
segregation process and consequently a reduction in costs for the treatment and final disposal of the waste.

According to the results obtained during the analyzed period, the MW segregation was approximately 397.6 tons with a generation capacity of $1.82 \mathrm{~kg} \mathrm{day}^{-1}$ per hospital bed. Comparing this factor with that reported by institutions in cities abroad, namely: Shanghai in China (0.95 kg day $\left.{ }^{-1}\right)$, reported by J. Hong et al. [26]; Korea (0.48 $\mathrm{kg} \mathrm{day}^{-1}$, obtained by Y. C. Jang et al. [9]; Istanbul in Turkey (1.68 $\mathrm{kg} \mathrm{day}^{-1}$ ), described by E. N. Korkut [25]; Italy (0.25 to $\left.3.5 \mathrm{~kg} \mathrm{day}^{-1}\right)$, reported by L. Liberti et al. [19], Britain or France (3.3 $\mathrm{kg} \mathrm{day}^{-1}$ ) and Norway (2.6 kg day ${ }^{-1}$ ), reported by M. Zamparas et al. [27], it can be said that the entity assessed has a high MW production compared to Asian institutions, is similar to Turkish health institutions and low when compared to European hospitals. This result coincides with the estimates given for Colombian IPHS with a capacity of average care reported by J. D. Moreno R. [37], $1.91 \mathrm{~kg}$ day-1 per hospital bed, showing that the organism evaluated could even be below the country average.

A predominant segregation of BW was determined, with $54.11 \%$, which translates into an approximate production of 215.1 tons, and a generation capacity of 0.98 $\mathrm{kg} \mathrm{day}^{-1}$ per hospital bed; followed by the UNHW with $41.53 \%$ (165.1 tons), with a production rate of $0.75 \mathrm{~kg} \mathrm{day}^{-1}$; and by the CPW with $4.37 \%$ (17.4 tons), and a production of $0.08 \mathrm{~kg} \mathrm{day}^{-1}$. This differs markedly with the diagnosis of European IPHS, such as those presented by M. Zamparas et al. [27], where a higher production of UNHW (79\%) was determined, than BW (17\%).

If the segregation of BW is confronted with that reported by E. N. Korkut [25], in cities such as Istanbul (Turkey), and cities in Latin American countries such as Brazil, as those provided by C. E. Da Silva et al. [21], it can be said that the production of these residues is considerably higher. These data can also be contrasted with the typical composition of MW determined by the WHO [38], in which case, it can be established that the studied IPHS generates more than five times the BW production expected by the WHO, almost half of UNHW, and a similar approach with respect to CPW. This could be an indication of the inefficiency in the HCWM process, which can lead to an additional cost for its treatment and greater risks for health and the environment.

Estimates show that the segregation of the BW subcategories in the IPHS are similar to those reported by the national government, through IDEAM [39]. The results reveal a BSW production of $81.3 \%$ (174.93 tons, $0.80 \mathrm{~kg} \mathrm{bed}^{-1} \mathrm{day}^{-1}$ ), $17.3 \%$ of PAW (37.15 tons, $0.17 \mathrm{~kg} \mathrm{bed}^{-1}$ day $^{-1}$ ), and 1.4\% of SMW (3.05 tons, $0.01 \mathrm{~kg} \mathrm{bed}^{-1}$ day $^{-1}$ ). Simultaneously, the generation of the CPW subcategories were: reagents and other $53.50 \%$ (9.29 tons, $0.04 \mathrm{~kg} \mathrm{bed}^{-1}$ day $^{-1}$ ), drugs and cytotoxic 35.19\% (6.11 tons, 0.03 $\mathrm{kg} \mathrm{bed}^{-1}$ day $^{-1}$ ), used oils 10\% (1.74 tons, $0.01 \mathrm{~kg} \mathrm{bed}^{-1}$ day $^{-1}$ ), heavy metals $1.12 \%$ (0.19 
tons, $0.0009 \mathrm{~kg} \mathrm{bed}^{-1} \mathrm{day}^{-1}$ ), and pressurized 0.18\% (0.03 tons, $0.0001 \mathrm{~kg} \mathrm{bed}^{-1}$ day $^{-1}$ ); higher for reagents and lower for drugs and cytotoxic, but similar in the case of the other categories, with respect to the data estimated by J. D. Moreno R. [37], for an IPHS of the city of Bogotá.

Meanwhile, the generation of UNHW was in a proportional order of: OW 76\% (125.47 tons, $0.57 \mathrm{~kg} \mathrm{bed}^{-1}$ day $^{-1}$ ), PW 15.04\% (24.84 tons, $0.11 \mathrm{~kg} \mathrm{bed}^{-1}$ day $^{-1}$ ), glass and the like $4.75 \%$ (7.85 tons, $0.04 \mathrm{~kg} \mathrm{bed}^{-1}$ day $^{-1}$ ), paper and cardboard 4.20\% (6.94 tons, $0.03 \mathrm{~kg} \mathrm{bed}^{-1}$ day $^{-1}$ ); lower than the amount reported by J. D. Moreno R. [37], for an IPHS of the city of Bogotá. This situation leads us to conclude again that the management procedures in the institution do not meet the expected efficiency expectations; consequently, recyclable waste is not fully utilized, thus hindering possible income for the IPHS.

According to the identified annual behavior, during 2019 there was an increasing trend regarding the segregation of UNHW and BW, as compared to the trend of 2018. While estimates show a monthly production in the interval of 6 to 7 tons for UNHW and 6 to 8 tons for BW during 2018, the intervals during 2019 were 6 to 9 tons and 8 to 10 tons, respectively. In accordance with E. N. Korkut [25], M. Zamparas et al. [27] and IDEAM [39], this could be due to an increased demand for health services, closely related to demographic growth, industrial development and other socioeconomic factors, elements that currently constitute a regional and national trend. In contrast, the CPW presented minimal variations, identifying a minimum production in November 2018 of 0.13 tons and a maximum of 0.95 tons in October 2019.

The analysis of the annual behavior of MW by subcategory allows us to express:

1. The BSW showed a trend of increase in production in the last months of 2019 and an opposite behavior during 2018, with production rates between 6 and 8.5 tons. PAWs presented a maximum production limit of close to 2 tons in the month of July 2018 and a lower limit of almost 1.3 tons in September and November (2018 and 2019). The SMW showed a similar behavior in both years, with an important difference during the month of April of the year 2019, where there was an abrupt rise in its production, reaching up to 0.28 tons.

2. The OW presented a gradual increase during the year 2019 (with a maximum close to 7 tons and a minimum of 5), whereas, during 2018, its production decreased steadily, reaching a minimum production during the month of December (4.5 tons). PWs show a progressive increase, reaching a maximum production close to 1.4 tons in the month of November 2019, 
and a minimum of 0.8 tons in January 2018. Something similar happened with paper and cardboard, which went from a production of between 0.15 to 0.2 tons in the first months of 2018 , to a production of between 0.4 and 0.55 tons at the end of 2019; almost three times the production of the previous year. The glass, on the other hand, showed an asymmetric behavior the first year of the diagnosis, and slightly varied in 2019, with a maximum of 0.44 tons in April and December 2018, a minimum of 0.2 tons in August of the same year, and a maximum of 0.36 at the beginning and end of 2019.

3. On the other hand, the CPWs, which did not exceed the ton of production per month during the diagnosis, show notable variations which prevent concise appraisals regarding their behavior. However, it can be inferred that their segregation does not depend directly on the increase in demand for health services; reactive residues and drugs are produced to a greater extent than pressurized ones, which could lead to an increase in costs for treatment and final disposal. It is also possible that the workers are performing an inadequate segregation of this type of waste, which prevents their trend from being clearly visualized.

In accordance with these assertions, it follows that the measures applied by the IPHS in order to better manage waste have been slightly favorable, despite the fact that the segregation of recyclables such as PW, paper and cardboard has increased significantly; these are not yet very evident in the generation of waste that represents risks to health and the environment. It should be remembered, as described by the WHO [6], that the best way to control the impact of medical waste is to produce less, thus, an effective way to achieve it, is to ensure effectively that only HWPCs are sent for final treatment, with a minimum or no contribution on behalf of the UNHW. To achieve this goal, it is recommended:

1. To include or reinforce continuous education or training programs regarding the correct segregation of waste within the entity for workers and users proposing, if possible, motivational and awareness mechanisms through the use of technological and informative tools, such as virtual platforms, videos, brochures, etc.

2. To have a control based on the continuous, systematic and coordinated registration of activities related to the handling and management of waste at the IPHS. 
3. To create or strengthen the environmental management group, which should be linked to the other dependencies of the institution, meet periodically and control the processes pre-established by it, in order to care for and protect the environment.

4. Through the environmental management group, identify threats and vulnerability regarding HCWM, contributing to the corporate risk map.

5. If applicable, formulate an internal plan for the inactivation of hazardous waste or contract the service with an external manager.

6. According to what is described by the Ministry of Health and Social Protection [2] and the Ministry of Environment and Health [3], it will be convenient to rethink and create some HCWM indicators, which will have to include mainly: indicators of destination, training, utilization benefits, and disabilities due to reported accidents from MW handling.

7. Likewise, a comprehensive management plan for hospital waste and the like should be established, compatible with the obligations required by government regulations and the financial and social context of the IPHS.

\section{REFERENCES}

[1] C. Ramírez and E. Gonzalez, "Methodological proposal for the inter-institutional management of wastes in health care centers in Uruguay," MethodsX, vol. 6, Jan. 2019, pp. 71-81. [Online]. doi: 10.1016/J.MEX.2018.11.022.

[2] M. de Salud y Protección Social, Decreto Número 780 de 2016. Colombia: Ministerio de Salud y Protección Social, 2016, pp. 1-672. [Online]. Available: https://www.minsalud.gov.co/ Normatividad_Nuevo/Decreto 0780 de 2016.pdf

[3] M. de Ambiente y Salud, Resolución número 01164. Colombia: Ministerio del Medio Ambiente y Salud, 2002, pp. 1-56. [Online]. Available: http://www.udea.edu.co/wps/wcm/ connect/udea/8ef2b54c-c7a3-4d32-8dde-ddf2c0bd9dc9/Resolución+1164+de+2002. pdf?MOD=AJPERES

[4] S. Çalıs and B. Arkan, "The Views of the Nursing Students about the Medical Wastes and their Effects on the Environmental and Human Health," Procedia - Soc. Behav. Sci., vol. 116, 2014, pp. 1472-1476. [Online]. doi: 10.1016/j.sbspro.2014.01.419. 
[5] L. Rushton, "Health hazards and waste management," Br. Med. Bull., vol. 68, 2003, pp. 183197. [Online]. doi: 10.1093/bmb/ldg034.

[6] World Health Organization (WHO), Safe management of wastes from health-care activities. Switzerland, 2014.

[7] E. S. Windfeld and M. S. L. Brooks, “Medical waste management-A review," J. Environ. Manage., vol. 163, 2015, pp. 98-108. [Online]. doi: 10.1016/j.jenvman.2015.08.013.

[8] P. D. Eagan and E. Joeres, "Development of a facility-based environmental performance indicator related to sustainable development," J. Clean. Prod., vol. 5, no. 4, 1997, pp. 269-278. [Online]. doi: 10.1016/s0959-6526(97)00044-9.

[9] Y. C. Jang, C. Lee, O. S. Yoon, and H. Kim, “Medical waste management in Korea," J. Environ. Manage., vol. 80, no. 2, 2006, pp. 107-115. [Online]. doi: 10.1016/j.jenvman.2005.08.018.

[10] A. Simon, M. Bernardo, S. Karapetrovic, and M. Casadesús, "Integration of standardized environmental and quality management systems audits," J. Clean. Prod., vol. 19, no. 17-18, 2011, pp. 2057-2065. [Online]. doi: 10.1016/j.jclepro.2011.06.028.

[11] A. Carvalho, A. F. Mimoso, A. N. Mendes, and H. A. Matos, "From a literature review to a framework for environmental process impact assessment index,” J. Clean. Prod., vol. 64, 2014, pp. 36-62. [Online]. doi: 10.1016/j.jclepro.2013.08.010.

[12] K. G. Papaspyropoulos, V. Blioumis, A. S. Christodoulou, P. K. Birtsas, and K. E. Skordas, "Challenges in implementing environmental management accounting tools: The case of a nonprofit forestry organization," J. Clean. Prod., vol. 29-30, 2012, pp. 132-143. [Online]. doi: 10.1016/j.jclepro.2012.02.004.

[13] C. R. Malaver Flor, R. J. Trullo Guerrero, J. A. Caicedo Muñoz, and J. A. Mosquera Bolaños, "Enfoque para el manejo de residuos no peligrosos aprovechables empleando una estación ecológica," Ing. Solidar., vol. 12, no. 20, 2016, pp. 107-120. [Online]. doi: 10.16925/ in.v12i20.1547.

[14] S. Bersimis and D. Georgakellos, "A probabilistic framework for the evaluation of products' environmental performance using life cycle approach and Principal Component Analysis," J. Clean. Prod., vol. 42, 2013, pp. 103-115. [Online]. doi: 10.1016/J.JCLEPRO.2012.10.038. 
Diagnosis Of Hospital, Hazardous and Similar Waste Management of an Institution Providing Health Services - IPHS

[15] M. K. Ghasemi and R. B. M. Yusuff, "Advantages and disadvantages of healthcare waste treatment and disposal alternatives: Malaysian scenario," Polish J. Environ. Stud., vol. 25, no. 1, 2016, pp. 17-25. [Online]. doi: 10.15244/pjoes/59322.

[16] C. Jiang, Z. Ren, Y. Tian, and K. Wang, "Application of best available technologies on medical wastes disposal / treatment in China ( with case study )," vol. 16, 2012, pp. 257-265. [Online]. doi: 10.1016/j.proenv.2012.10.036.

[17] B. K. Lee, M. J. Ellenbecker, and R. Moure-Ersaso, "Alternatives for treatment and disposal cost reduction of regulated medical wastes," Waste Manag., vol. 24, no. 2, Jan. 2004, pp. 143-151. [Online]. doi: 10.1016/j.wasman.2003.10.008.

[18] Y. Chen, L. Liu, Q. Feng, and G. Chen, "Key Issues Study on the Operation Management of Medical Waste Incineration Disposal Facilities," Procedia Environ. Sci., vol. 16, 2012, pp. 208213. [Online]. doi: 10.1016/j.proenv.2012.10.029.

[19] L. Liberti, A. Tursi, N. Costantino, L. Ferrara, and G. Nuzzo, "Optimization of infectious hospital waste management in Italy: Part II. Waste characterization by origin," Waste Manag. Res., vol. 14, no. 5, Oct. 1996, pp. 417-431. [Online]. doi: 10.1006/wmre.1996.0042.

[20] J. I. Blenkharn, "Standards of clinical waste management in UK hospitals," J. Hosp. Infect., vol. 62, no. 3, Mar. 2006, pp. 300-303. [Online]. doi: 10.1016/j.jhin.2005.08.005.

[21] C. E. Da Silva, A. E. Hoppe, M. M. Ravanello, and N. Mello, "Medical wastes management in the south of Brazil," Waste Manag., vol. 25, no. 6 SPEC. ISS., Jan. 2005, pp. 600-605. [Online]. doi: 10.1016/j.wasman.2004.03.002.

[22] J. I. Blenkharn, "Medical wastes management in the south of Brazil," Waste Manag., vol. 26, no. 3, 2006, pp. 315-317. [Online]. doi: 10.1016/j.wasman.2005.09.002.

[23] D. Komilis, N. Makroleivaditis, and E. Nikolakopoulou, "Generation and composition of medical wastes from private medical microbiology laboratories," Waste Manag., vol. 61, Mar. 2017, pp. 539-546. [Online]. doi: 10.1016/j.wasman.2017.01.033.

[24] M. H. Dehghani, H. D. Ahrami, R. Nabizadeh, Z. Heidarinejad, and A. Zarei, "Medical waste generation and management in medical clinics in South of Iran," MethodsX, vol. 6, 2019, pp. 727-733. [Online]. doi: 10.1016/j.mex.2019.03.029. 
[25] E. N. Korkut, "Estimations and analysis of medical waste amounts in the city of Istanbul and proposing a new approach for the estimation of future medical waste amounts," Waste Manag., vol. 81, Nov. 2018, pp. 168-176. [Online]. doi: 10.1016/j.wasman.2018.10.004.

[26] J. Hong, S. Zhan, Z. Yu, J. Hong, and C. Qi, "Life-cycle environmental and economic assessment of medical waste treatment," J. Clean. Prod., vol. 174, Jan. 2018, pp. 65-73. [Online]. doi: 10.1016/j.jclepro.2017.10.206.

[27] M. Zamparas et al., "Medical waste management and environmental assessment in the Rio University Hospital, Western Greece," Sustain. Chem. Pharm., vol. 13, Sep. 2019, p. 100163. [Online]. doi: 10.1016/j.scp.2019.100163.

[28] M. M. A. El-salam, "Hospital waste management in El-Beheira Governorate, Egypt," J. Environ. Manage., vol. 91, no. 3, 2010, pp. 618-629. [Online]. doi: 10.1016/j.jenvman.2009.08.012.

[29] M. Chaerul, M. Tanaka, and A. V. Shekdar, "A system dynamics approach for hospital waste management," Waste Manag., vol. 28, no. 2, 2008, pp. 442-449. [Online]. doi: 10.1016/j. wasman.2007.01.007.

[30] A. Serrano Santoyo, V. A. Rojas Mendizabal, and C. Castillo Olea, "Marco de referencia para la gestión de programas en E-Salud," Ing. Solidar., vol. 13, no. 23, 2017, pp. 29-39. [Online]. doi: 10.16925/in.v23i13.1982.

[31] Us-epa, Region, Sesd, Athens, and Ga, "Wastewater Sampling," Athens, Georgia, 2017. Accessed: Apr. 20, 2020. [Online]. Available: https://www.epa.gov/sites/production/files/2017-07/documents/wastewater_sampling306_af.r4.pdf.

[32] D. Duncan, F. Harvey, M. Walker, and A. water Quality, Water and wastewater sampling, no. June. 2007.

[33] A. Peña-Álvarez and A. Castillo-Alanís, "Identificación y cuantificación de contaminantes emergentes en aguas residuales por microextracción en fase sólida-cromatografía de gases-espectrometría de masas (MEFS-CG-EM)," TIP, vol. 18, no. 1, Jun. 2015, pp. 29-42. [Online]. doi: 10.1016/j.recqb.2015.05.003.

[34] C. Binder, H. P. Bader, R. Scheidegger, and P. Baccini, "Dynamic models for managing durables using a stratified approach: The case of Tunja, Colombia," Ecol. Econ., vol. 38, no. 2, Aug. 2001, pp. 191-207. [Online]. doi: 10.1016/S0921-8009(01)00155-0. 
Diagnosis Of Hospital, Hazardous and Similar Waste Management of an Institution Providing Health Services - IPHS

[35] I. Sanchez, L. Mendoza, A. L. Rincón, D. P. Aguirre, and J. J. Builes, "Ancestry evaluation in a population sample of the Tunja city, Department of Boyacá - Colombia," Forensic Sci. Int. Genet. Suppl. Ser., vol. 7, no. 1, Dec. 2019, pp. 695-697, doi: 10.1016/j.fsigss.2019.10.142.

[36] R. Rijo, R. Martinho, and D. Ermida, "Developing an Enterprise Architecture Proof of Concept in a Portuguese Hospital," in Procedia Computer Science, vol. 64, Jan. 2015, pp. 1217-1225. [Online]. doi: 10.1016/j.procs.2015.08.511.

[37] J. D. Moreno R., "Diagnóstico situacional de la gestión integral de los residuos sólidos hospitalarios en Colombia y proyectos de cooperación,” Bogotá, Feb. 2012. Accessed: Apr. 22, 2020. [Online]. Available: https://www.paho.org/col/index.php?option=com_docman\&view=download\&category_slug=publicaciones-ops-oms-colombia\&alias=1360-if-diagn-residuos-opsswiss-2012\&ltemid=688.

[38] W. H. Organization, "Safe management of wastes from health-care activities," Geneva, Switzerland, 2017. Accessed: Apr. 22, 2020. [Online]. Available: http://apps.who.int/ bookorders.

[39] I. de H. M. y E. A. IDEAM, "Informe nacional de residuos o desechos peligrosos en Colombia," Bogotá, 2017. Accessed: Apr. 23, 2020. [Online]. Available: http://documentacion.ideam.gov. co/openbiblio/bvirtual/023849/Informe_RESPEL_2017.pdf. 